\title{
Unilateral Dyshidrosiform Pemphigus Vulgaris
}

\author{
Manju Daroach ${ }^{1}$ Dipankar De ${ }^{1}$ Sanjeev Handa ${ }^{1}$ Rahul Mahajan ${ }^{1}$ Vikarn Vishwajeet ${ }^{2} \quad$ Uma N. Saikia²
}

${ }^{1}$ Department of Dermatology, Venereology and Leprology, Postgraduate Institute of Medical Education and Research, Chandigarh, India

2Department of Histopathology, Postgraduate Institute of Medical Education and Research, Chandigarh, India

\begin{abstract}
Address for correspondence Dipankar De, MD, Department of Dermatology, Venereology and Leprology, Postgraduate Institute of Medical Education and Research, Sector 12, Chandigarh 160012, India (e-mail: dr_dipankar_de@yahoo.in).
\end{abstract}

\begin{abstract}
Keywords

- pemphigus vulgaris

- dyshidrosiform

- unilateral

Pemphigus vulgaris is an autoimmune disease characterized by fluid-filled blisters over body and mucosal surfaces. Localized pemphigus is a rare presentation of the disease. There are few reports of localized pemphigus in literature presenting as esophageal involvement, recurrent paronychia, conjunctival mass, foot ulcers, discoloration of toes with hyperkeratotic skin lesions, verrucous lesions, and dyshidrosiform pemphigus vulgaris. We present a case of dyshidrosiform pemphigus involving a foot following trauma. Histopathology and direct immunofluorescence confirmed our diagnosis. In our patient, the disease started as localized dyshidrosiform pemphigus and later became generalized. This unusual presentation led to a delay in diagnosis and proper treatment in this patient. Physicians should be aware of such rare presentations to aid in the timely diagnosis and management of such patients.
\end{abstract}

Pemphigus vulgaris is an autoimmune bullous disease clinically characterized by flaccid cutaneous blisters and erosions with mucosal involvement. Unilateral or localized forms of pemphigus have been reported in literature. Some rare presentations of pemphigus vulgaris include isolated esophageal involvement, recurrent paronychia, conjunctival mass, foot ulcers, discoloration of toes with hyperkeratotic skin lesions, verrucous lesions, and dyshidrosiform pemphigus vulgaris. We present a case of unilateral dyshidrosiform pemphigus vulgaris following limb trauma.

A 35-year-old man presented with tense as well as flaccid vesicular lesions and crusting on right foot. A known case of pemphigus vulgaris for past 10 years, he had been treated with dexamethasone pulse therapy and azathioprine, followed by rituximab. He was in remission for past 3 years before this episode. Four months back he had fracture right femur for which he was operated and internal fixation of fracture was done. Four weeks following the surgery, he developed vesicular lesions on his right sole followed by pustulation and crusting. He was being treated as infected eczema from another facility with oral antibiotics and prednisolone with minimal relief. Subsequently, he developed flaccid vesicles on the scar of surgery for fracture. There was no lesion elsewhere in the body. Two months later, he developed oral erosions and few similar lesions on upper trunk and upper limbs. On examination, there were tense vesicles and yellowish brownish crust on the right sole and its lateral margin (-Fig. 1). Flaccid fluid-filled vesicles and erosions were present at the scar site (-Fig. 2). Few scattered lesions were seen on the chest, abdomen, upper back, and upper limbs. Differential diagnoses at the time of presentation included localized dyshidrosiform pemphigus vulgaris, vesicular eczema, bullous tinea pedis, and bullous erythema multiforme.

Tzanck smear from lesions on sole, scar area, and oral mucosa showed acantholytic cells. Histopathology (-Fig. 3A) and direct immunofluorescence (-Fig. 3B) were suggestive of pemphigus vulgaris. With a diagnosis of dyshidrosiform pemphigus vulgaris followed by generalization, he was treated with prednisolone $40 \mathrm{mg} /$ day and subsequently with rituximab $1 \mathrm{~g}$ two doses 2 weeks apart and had improvement.

Dyshidrosiform pemphigoid is a well-known variant of localized pemphigoid presenting as vesiculobullous lesions on palms and soles. ${ }^{1}$ Dyshidrosiform pemphigus, however, is rarely seen $^{2}$ ( - Table 1). Palmoplantar involvement in pemphigus vulgaris is a poor prognostic indicator. ${ }^{3}$ The presentation
DOI https://doi.org/ $10.1055 / \mathrm{s}-0040-1713184$ ISSN 0379-038X.
(C) 2020. National Academy of Medical Sciences (India).

This is an open access article published by Thieme under the terms of the Creative Commons Attribution-NonDerivative-NonCommercial-License, permitting copying and reproduction so long as the original work is given appropriate credit. Contents may not be used for commercial purposes, or adapted, remixed, transformed or built upon. (https://creativecommons.org/licenses/by-nc-nd/4.0/).

Thieme Medical and Scientific Publishers Pvt. Ltd. A-12, 2nd Floor, Sector 2, Noida-201301 UP, India 


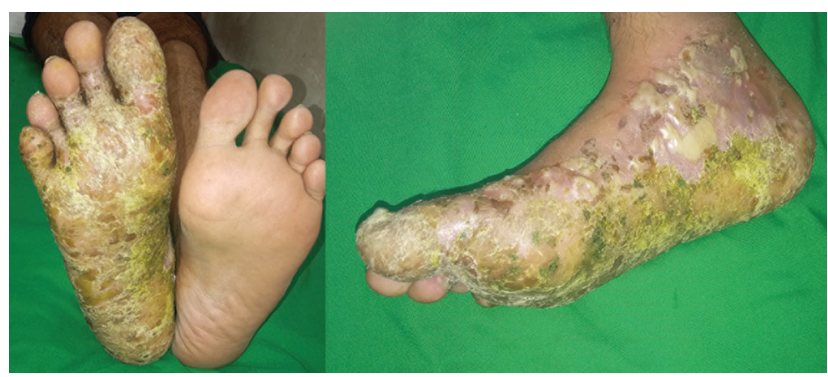

Fig. 1 Tense blisters and crusting on sole of right foot and lateral margin.

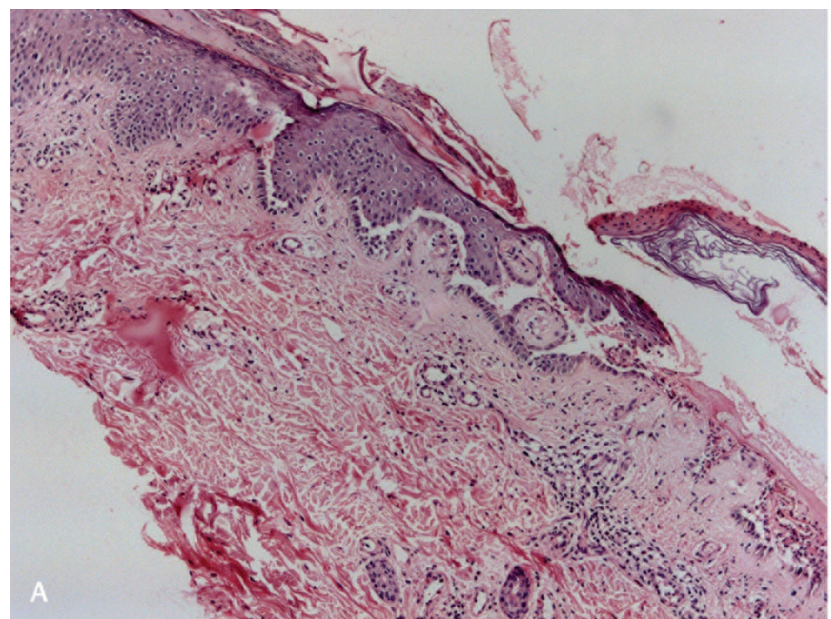

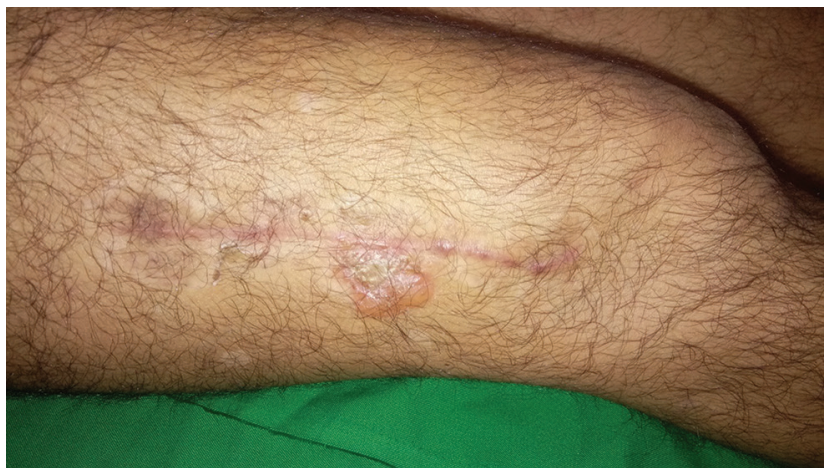

Fig. 2 Flaccid clear fluid filled blister on scar area on right thigh.

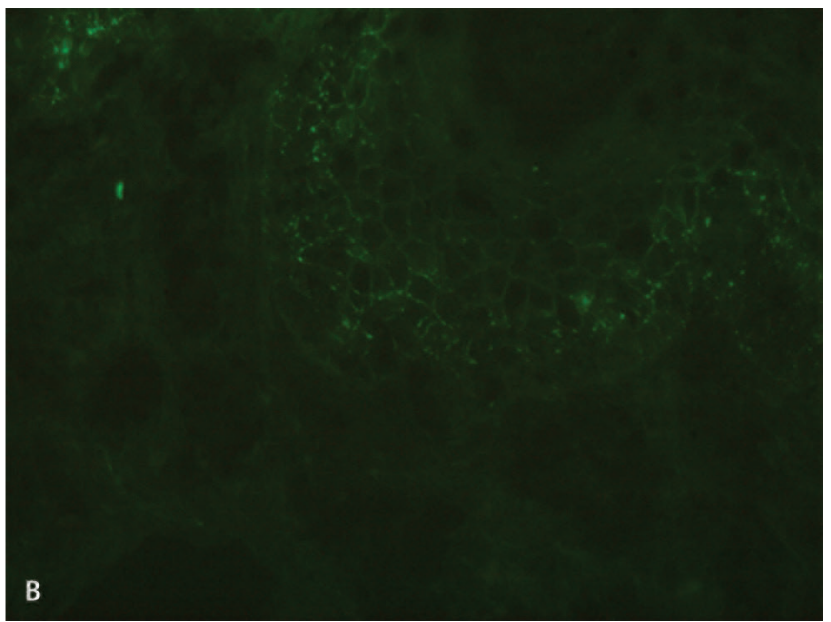

Fig. 3 (A) Histopathology (hematoxylin and eosin stain, 20X magnification) shows suprabasal cleft with row of tombstones and mild perivascular inflammatory infiltrate in dermis. (B) Direct immunofluorescence study highlights intraepidermal deposition of immune-reactant in fish net like pattern.

Table 1 Summary of previous reported cases of dyshidrosiform pemphigus

\begin{tabular}{|c|c|c|c|c|c|}
\hline $\begin{array}{l}\text { Serial } \\
\text { no. }\end{array}$ & Study & $\begin{array}{l}\text { Number of patients } \\
\text { reported, age }\end{array}$ & Clinical description & Proposed mechanism & Treatment \\
\hline 1 & Gharami et al, $2010^{2}$ & $\begin{array}{l}\text { 1, 36-year-old female, } \\
\text { known case of pemphi- } \\
\text { gus vulgaris for } 6 \text { years }\end{array}$ & $\begin{array}{l}\text { Vesicobullous eruption } \\
\text { with crusting on soles, } \\
\text { few lesions on trunk } \\
\text { Characteristic histo- } \\
\text { pathology and direct } \\
\text { immunofluorescence }\end{array}$ & $\begin{array}{l}\text { Irregular } \\
\text { self-medication }\end{array}$ & $\begin{array}{l}\text { Prednisolone and } \\
\text { cyclophosphamide }\end{array}$ \\
\hline 2 & $\begin{array}{l}\text { Borradori and } \\
\text { Harms, } 1994^{7}\end{array}$ & $\begin{array}{l}\text { 1, } 48 \text {-year-old male, } \\
\text { known case of pemphi- } \\
\text { gus vulgaris for } 7 \text { years }\end{array}$ & $\begin{array}{l}\text { Vesiculopustular and } \\
\text { bullous eroded lesions } \\
\text { on left sole, diagnosed } \\
\text { as bullous tinea pedis } \\
\text { Treated with antifun- } \\
\text { gals, relapse of similar } \\
\text { lesions in } 10 \text { days at } \\
\text { same site } \\
\text { Characteristic histo- } \\
\text { pathology and direct } \\
\text { immunofluorescence }\end{array}$ & $\begin{array}{l}\text { Keratinolytic enzymes } \\
\text { induced inflamma- } \\
\text { tory changes leading } \\
\text { to modification and } \\
\text { increased expression of } \\
\text { pemphigus antigen }\end{array}$ & Prednisolone \\
\hline 3 & Present case & $\begin{array}{l}\text { 1, } 35 \text {-year-old male, } \\
\text { known case of pem- } \\
\text { phigus vulgaris for } \\
10 \text { years }\end{array}$ & $\begin{array}{l}\text { Tense blisters and } \\
\text { crusting on right foot, } \\
\text { with few lesions on } \\
\text { trunk, upper limb and } \\
\text { oral mucosa } \\
\text { Characteristic histo- } \\
\text { pathology and direct } \\
\text { immunofluorescence }\end{array}$ & $\begin{array}{l}\text { Local inflammatory } \\
\text { changes post trauma } \\
\text { and surgery }\end{array}$ & $\begin{array}{l}\text { Prednisolone and } \\
\text { rituximab }\end{array}$ \\
\hline
\end{tabular}


in our patient was unusual as the disease relapsed as pompholyx like lesions, initially confined to the limb that had sustained trauma. Exact pathogenesis of dyshidrosiform pemphigus is unknown. This presentation can be explained by the hypothesis proposed in dyshidrosiform pemphigoid. Local inflammatory process can uncover the masked antigen and trigger the disease at local site. ${ }^{4}$

Our patient had trauma in his right limb followed by internal fixation of fracture. This may have led to inflammation and local edema that might have triggered an inflammatory response unmasking or modulating pemphigus antigen similar to Koebner's phenomenon. In a report of dyshidrosiform pemphigoid secondary to venous stasis, the pathogenesis was attributed to local inflammation analogous to koebnerisation. ${ }^{5}$ Dyshidrosiform pemphigoid can precede or occur concurrently with generalized form. ${ }^{6}$

In our patient, the disease started as localized dyshidrosiform pemphigus and later became generalized. Other possibilities considered in our patient were infected dyshidrosiform eczema, bullous tinea pedis, and bullous erythema multiforme. Dyshidrosiform eczema and bullous erythema multiforme is usually bilateral and was excluded based on Tzanck smear positivity and histopathology/direct immunofluorescence characteristic of pemphigus. Tinea pedis was ruled out with the help of potassium hydroxide mount examination of blister fluid that was negative.
This unusual presentation led to a delay in diagnosis and proper treatment in this patient. This case is being presented to highlight a rare morphologic variant of pemphigus.

\section{Conflict of Interest}

None declared.

\section{References}

1 Michelerio A, Croci GA, Vassallo C, Brazzelli V. Hemorrhagic vesiculobullous eruption on the palms and the soles as presentation of dyshidrosiform bullous pemphigoid. JAAD Case Rep 2017;4(1):61-63

2 Gharami RC, Kumar P, Mondal A, Ghosh K. Dyshidrosiform Pemphigus vulgaris: report of an unusual case. Dermatol Online J 2010;16(7):10

3 Vaishnani JB, Bosamiya SS. Pemphigus: active or inactive? Indian J Dermatol 2009;54(2):186-188

4 Levine N, Freilich A, Barland P. Localized pemphigoid simulating dyshidrosiform dermatitis. Arch Dermatol 1979;115(3): 320-321

5 Shi CR, Charrow A, Granter SR, Christakis A, Wei EX. Unilateral, localized bullous pemphigoid in a patient with chronic venous stasis. JAAD Case Rep 2018;4(2):162-164

6 Lupi F, Masini C, Ruffelli M, Puddu P, Cianchini G. Dyshidrosiform palmoplantar pemphigoid in a young man: response to dapsone. Acta Derm Venereol 2010;90(1):80-81

7 Borradori L, Harms M. Podopompholyx due to pemphigus vulgaris and Trichophyton rubrum infection. Report of an unusual case. Mycoses 1994;37(3-4):137-139 